\title{
NATURE/NURTURE AND THE ANTHROPOLOGY OF FRANZ BOAS AND MARGARET MEAD AS AN AGENDA FOR REVOLUTIONARY POLIIICSI
}

\author{
Sidney M. Greenfield \\ University of Wisconsin-Milwaukee - Estados Unidos
}

\begin{abstract}
There is much more involved in the nature/nurture debate than an abstract theoretical disagreement among dispassionate scientists. Each side of the debate leads logically to significantly different views of the social order and holds different implications for social policy. In this paper I shall argue that Boas' Anthropology with its emphasis on cultural relativism was as much a social and political agenda as it was a scientific theory. The positions on public policy issues he opposed were informed (and rationalized) by what its advocates claimed to be science. To be able to counter the discriminatory policy proposals that followed from this science, it was necessary for Boas both to challenge its validity and then replace it with an alternative that would support a more liberal political agenda. This chapter of anthropology's history gains relevance in today's context as neoevolutionary, reductionist theories once more provide "scientific" support for conservative, separatist and often discriminatory social policies.
\end{abstract}

Keywords: cultural relativism, Franz Boas, History of Anthropology, racial prejudice.

\footnotetext{
${ }^{1}$ The inspiration to write this paper emerged while I was planning a conference commemorating the centenary of Margaret Mead with Professor Morton Klass. We intended to examine the "scientific" claims of sociobiology, evolutionary psychology and other forms of NeoDarwinian reductionism that attribute human behavior exclusively to genetic factors and to explore their implications for public policy. Due to Dr. Klass' sudden death in April 2001, the conference was put on hold.

Morton Klass and I were fellow students at Columbia University in the mid-1950s, more than a decade after the death of Franz Boas. At the time Boas' legacy already was under attack by those wishing to make the discipline more scientific. We both did study with Margaret Mead among others influenced by Boas.

This paper is dedicated to my friend and colleague Morton Klass who both professionally and personally embodied the values attributed in the paper to Boas, Mead and others at Columbia University and also helped make anthropology more scientific by clarifying the concept of culture through doing the kind of ethnographic fieldwork its understanding requires.
}

Horizontes Antropológicos, Porto Alegre, ano 7, n. 16, p. 35-52, dezembro de 2001 
Resumo: O debate natureza/cultura é muito mais do que um desentendimento teórico e abstrato entre cientistas desapaixonados. Cada lado do debate leva a visões diferentes da ordem social e traz implicações diferentes para políticas sociais. Neste artigo, sugiro que a Antropologia de Boas, com sua ênfase no relativismo cultural, tanto quanto uma teoria científica, foi um programa social e político. As posturas de política pública às quais ele se opunha eram informadas (e racionalizadas) por algo apresentado por seus proponentes como ciência. Para combater as propostas discriminatórias que decorriam desta ciência, cabia a Boas desafiar sua validade e substituí-la por uma alternativa que daria apoio a uma agenda política mais liberal. Esse capítulo da história da antropologia assume maior relevância no contexto atual em que teorias néo-evolucionistas e reducionistas mais uma vez fornecem uma base "científica" para políticas sociais conservadoras, separatistas e freqüentemente discriminatórias.

Palavras-chave: Franz Boas, história da antropologia, preconceito racial, relativismo cultural.

As history shows, when translated into the political arena, scientificsounding arguments often serve as rationalizations for doing harm to the most vulnerable elements of society.

Nora Ellen Groce and Jonathan Marks (2000, p. 821)

The discovery that the past might have gone another way is simultaneously the discovery that the future can be different.

James Carroll (2001, p. 63)

In The Culture of Critique: An Evolutionary Analysis of Jewish Involvement in Twentieth-Century Intellectual and Political Movements, Kevin MacDonald, building on recent attacks on JewishAmerican intellectuals and their scholarly contributions, claims that the anthropological enterprise developed by Franz Boas and his students at Columbia University in the early years of the twentieth century was more of an ethno-political agenda than science (1998, chapter 2). Rather than counter MacDonald's baseless ethnic slurs, in this paper I shall accept his 
contention that Boas' anthropology was as much a social and political agenda as it was a scientific theory. The positions on public policy issues he opposed were informed (and rationalized) by what its advocates claimed to be science. To be able to counter the discriminatory policy proposals that followed from this science, it was necessary for Boas both to challenge its validity and then replace it with an alternative that would support a more liberal political agenda.

Boas did not invent the idea of fashioning scientific theory for the purpose of advancing social and political goals. The practice has been part of Western cultural tradition since the Enlightenment. By the twentieth century it was so commonplace that most scholars, especially those who favored the political and economic status quo, had ceased to make explicit the relationship between their scientific undertakings and proposals for public policy. They chose instead to maintain, and perhaps even mistakenly believe, that they were doing some kind of value free, or "pure science". This enabled them to charge those, such as Boas, who opposed the policies their undertakings endorsed, with using science to advance a socio-political agenda.

Boas and his followers openly opposed discrimination and prejudice and, since these practices were rationalized and justified by theories that rested on an evolutionary metaphor, they mounted a systematic attack against all forms of evolutionary thinking. The need for an alternative theory to replace evolutionism resulted in the formulation of cultural relativism with its emphasis on culture as learned and changeable. The political backlash against public policies and programs put into place based on this thinking in the post World War II era, combined with new directions taken within the discipline, explains the vitriolic present day attacks on Boas and his anthropology by those, such as MacDonald, who oppose the policies he advocated. It is interesting to note that many of these present day policies, that resemble those prevailing in the nineteenth and early twentieth centuries, base their claims on what are reformulated evolutionary, racial theories. Acknowledging that the science on all sides of public issues may be used to justify positions on social policies will enable us to see the debate in a fresh light.

The European nations that adopted Enlightenment thinking, and the scientific revolution of which it is a product, first encountered substantial 
numbers of peoples and cultures different from themselves after the discoveries and expansion of the fifteenth and sixteenth centuries ${ }^{2}$ when they divided up the world to make it into their colonies and later incorporated specific parts of it into their respective colonial empires. The diverse peoples had to be dealt with administratively although they were in far away places and did not have to be encountered and interacted with on a daily basis by either ordinary citizens or policy makers. The only Europeans who had to be concerned with the multiplicity of others were the merchants who traded with them, members of the military who conquered and then policed them, civil servants who ruled them and the officials and intellectuals who helped shape and implement the policies that became the laws that governed them.

During the centuries following the discoveries, large amounts of information describing the peoples of the world physically and reporting on their behaviors, especially behaviors that differed significantly from those of the Christian elites of Western Europe who thought and wrote about them, were being sent back home and accumulating. The question this growing body of knowledge raised for the intellectual community was how to account for and explain the great range of diversity in both physical form and behavior found among the peoples of the world ${ }^{3}$. The answer, as it was to be when Thomas Kuhn (1970, p. 3-4) later formalized the question as the starting point for science ${ }^{4}$, was in metaphor. That is, the world of diverse humanity would be likened to something familiar (and understood by thinking Europeans) that would make comprehensible that which was complex and confusing because it was unknown.

By the time of the Enlightenment, after scientific thought had been separated from religion, the dominant imagery applied in thinking about the peoples of the world and their diverse behaviors was that of an upwardly

\footnotetext{
2 This statement must be modified to acknowledge the role of Jews as the ever-present "other" in the Christian religious tradition that grew out of the rubble of the disintegration of the Roman Empire to dominate European belief and thinking up to the present (Carroll, 2001). Although the earliest Christians were similar to the Jews biologically, the Europeans to adopt the faith later - who were different - used the physical features that differentiated the groups as distinguishing negative makers. The Africans, Asians and peoples of the Western Hemisphere discovered during the expansion differed even more in terms of their looks and behaviors.

3 The explanations, of course, would have to support the continuing dominance of the others by the governments of the nations of Europe.

${ }^{4}$ What must the world be like for man to know it? (Kuhn, 1970).
} 
slopping line, or a ladder, with each group, or their characteristics, placed hierarchically on rungs in descending order down from Europeans who were placed solidly at the top. This imagery, as Robert Nisbet (1969) noted, was derived from Greek thinking that likened human society to a living organism whose growth, from birth to death, was used to explain the behavior of social groups. For the Greeks, and the Romans to follow them, each of the many peoples in the world was assumed to have its own distinctive growth cycle. The Church fathers substituted the idea of a single humanity whose growth manifested itself in a series of epochs or stages. Secular thinkers adopted this imagery of developmental stages as their means of organizing the large amount of data accumulating on human populations. In some scenarios proposed, total societies were placed in an ascending sequence on the ladder that was believed to demonstrate the evolution of human society. In others, isolated pieces of information, describing some aspect of the religious, political, or other behavior of a particular group were taken out of their lived context and placed in one or another of the categories of what was presented as a universalistic developmental sequence (of religion, family, etc.) offered as another view of the evolution of humanity. Since the standard for which behaviors were to be considered most advanced were those of the intellectuals who were the authors of the schemas, the data that differed most from their own beliefs and practices were taken to represent the earliest or most primitive stages of human life. The remaining categories were placed in ascending order to represent more advanced or developed stages according to how closely each approximated the social practices of the writer.

The imagery of hierarchically arranged stages of development, that came to be know as the theory of cultural evolution, took an unanticipated twist when it was placed within the Linnaean scheme of biological classification. Previously, the focus in ordering the data on human diversity was primarily the behaviors of peoples in their social groups with the physical characteristics of the actors being secondary ${ }^{5}$. Now the physical characteristics of the races, the subcategories of the single species into which all humanity was placed, were equated with behaviors. Consequently,

\footnotetext{
${ }^{5}$ The Linnaean system was intended to classify all forms of life. It had unanticipated consequences when applied in terms of the framework of the metaphor of developmental stages to human populations.
}

Horizontes Antropológicos, Porto Alegre, ano 7, n. 16, p. 35-52, dezembro de 2001 
race and social and cultural behavior came to be fused and seen as interdependent. The assumption, which is still an unsubstantiated premise in racist arguments, was that the former, the biological, was the cause of the latter, or cultural.

The racial categories, in what came to be a variant of evolutionary thinking, were placed on the steps of the ladder, again starting with the Western Europeans - now as a race, or series of sub-races - at the top with the others in descending order down to those races most different from them. Those at the lower end were assumed to be less advanced biologically and behaviorally than those above them and especially those at the top.

Without then examining the relationship between the biological and the social, the evolutionists assumed, as their intellectual descendants still do today, the ontological priority of what later became the nature/nurture oppositional debate. This enabled them to focus on what for them were more pressing (political) questions.

As long as the others were in distant places the practical consequences of this had no immediate impact on the peoples of the nations to which the writers belonged. Except for colonial administrators, merchants and soldiers, the policy implications of evolutionary theory and its racist variant did not impact on the daily lives of the peoples of Western Europe. This, of course, was not the case in the United States, or in Western Europe today after the post World War II immigration of large numbers of former colonial populations.

Unlike the polities of Western Europe, the United States first came into being as a colony. The earliest wave of primarily Anglo-Saxon settlers succeeded in pushing the native peoples they encountered far enough into the western interior so that by the time it won its independence most of these "others" were sufficiently far away so that they did not have to be dealt with on a daily basis. Interestingly, these indigenous peoples were called "savages" by the Europeans, a name used for one of the earlier stages in most schemes of human evolution. The peoples from Africa, brought as slaves, who generally were assigned to the least evolved category, represented a special situation to which I shall return shortly.

This demographic situation was to change irrevocably when following its industrialization in the early to mid-nineteenth century the United States began receiving large numbers of immigrants. Between 1880 and 1920 some 
tens of millions of people, mostly from Central, Southern and Eastern Europe, who differed both in their physical appearances as well as in their linguistic, religious and other social behaviors from the Anglo-Saxons, entered the country. How these differences were to be explained would determine the way they would be treated and incorporated into the body politic.

The first example of diversity Americans had coped with - aside from the native peoples who had been removed physically, or at times massacred - were the Africans who had been brought during the colonial period to work the plantations of the south. According to the racial variants of evolutionary theory then prevalent in Europe, which were accepted and used to justify bondage in the United States, Africans were at the bottom of the evolutionary scale, peoples whose innate abilities were believed to be so minimal that they were placed even below the indigenous people. Their descendants were to remain, to paraphrase Carroll (2001, p. 16), the extreme negative of humanity in (American) popular mythology.

Since so many of the slave masters were among the political elites who participated in the writing of the American constitution and in framing the laws of the land that set out what were to be acceptable codes of conduct governing social relations, the legal system of the United States had built into it a special status for Africans and their descendants that limited their participation in the institutions of national life. These slave codes, followed by the regulations supporting segregation and Jim Crow after emancipation, constituted an extreme model for the treatment of some post-Civil War immigrants. In the United States, then, racist evolutionary theories already were in place as an explanation for diversity. It is not surprising that they were used in public debates on the policies that would affect the extent to which the new arrivals would be able to participate in national economic, political and social life. The future of these immigrants might have depended on where they, as members of groups or categories, would be placed on the imaginary ladder. Furthermore, the extent to which any specific group could be shown to approximate Africans, Indians, or others near the bottom of the ladder who were assumed to be biologically and mentally inferior (Stocking, 1968), would greatly limit the opportunities that would be available to them; and, in the extreme, this would lead to proposals ranging from eugenics to the closing off of immigration. 
Franz Boas came to the United States at the beginning of the largescale immigration in the late 1880s. He was one of the many newcomers whose future would be influenced by public debates over the abilities and potentials (or lack thereof) of the various groups of newcomers. By his late twenties he already had earned a Ph.D. in his native Germany and had served his compulsory year in its military. He chose an academic career and a life in the United States. "What I want to live and die for," he wrote "is equal rights for all, equal possibilities to learn and work for poor and rich alike!" (Cole, 1983, p. 37).

Born in 1858 into a family that strongly espoused the principles of the unsuccessful revolution of 1848, Boas, like many German Jews of the period, passionately embraced its beliefs that included the value of science, its application to acquire knowledge that would improve the human condition and freedom for the individual to better himself while contributing to advancing society and the world around him ${ }^{6}$.

Among the members of this politically liberal, intellectually selfconscious group that influenced Boas in his formative years was Rudolph Virchow, "a physician, pathologist, scientist and radical activist, who was prominent in German science and politics" (Lewis, in press). Boas admired and emulated Virchow (Stocking, 1974, p. 22) and took a course in anthropometry with him before embarking on a field trip to Baffin Island. After participating in daily life there, Boas developed great respect for the Inuit people and for their customs. He realized how little was actually known about them, or many other small-scale, marginal (then called primitive) groups like them, other than the implications to be deduced from the place assigned them in the varying evolutionary schemas. What he was to learn about the Inuit, and other people he was to study as his career unfolded, led him to question the accuracy of the rigid system on which evolutionary thinking was based. As a result, he systematically opposed all forms of classifying peoples into categories, insisting instead on the importance of individuality. Given the social and political implications of evolutionary theories for the American society to which he committed himself, Boas first task was to challenge their scientific accuracy, which he

\footnotetext{
6 Their heroes, as Lewis (in press) notes, included Kant, Herder, Goethe, Schiller, Lessing, Moses Mendelssohn, Beethoven and the Von Humbolt brothers.
}

Horizontes Antropológicos, Porto Alegre, ano 7, n. 16, p. 35-52, dezembro de 2001 
would do both theoretically and with ethnographic data similar to what he collected on Baffin Island. More importantly, he would re-conceptualize anthropology, which was dominated at the time by evolutionary thinking (Harris, 1968), transforming it into the science that, in his view, would improve conditions by advancing his humanistic and individualistic beliefs.

Boas began his re-formulation of anthropology by taking the evolutionary metaphor and turning it over on its side. The result was a view of humanity in which each group, or culture, the term he used to refer to the total way of life of each population, became in a sense like the individuals Boas so greatly admired, each unique and distinctive with its own practices, values and worth. In terms of this new framework, Western Europeans and their former North American colonials no longer would represent the pinnacle and standard by which others were to be judged. Each culture instead was to be seen as the product of its own unique history that resulted in a set of beliefs, values and behaviors that were to be accepted on par, but different from, those of Western Europe and North America and each other. The implications of this imagery came to be known as cultural relativism.

The behavior of each individual, always foremost in Boas' thinking, was to be understood and judged exclusively in terms of the standards prevailing in the culture into which he had been born and raised. More importantly, Boas and his followers proceeded with the assumption that human behavior was learned rather than the inevitable consequences of biology, climate or any other factors. Furthermore, Boas was to take the lead in promoting the importance of ethnographic studies - that would lead to the systematic collection of data on the lives and cultures of peoples hereto-fore unstudied directly by scholars. This cornerstone of the anthropological science he was building was to be no greater in his overall concerns than the effort he would devote to helping build the scientifically based, rational culture that he hoped would emerge in the United States.

Boas view of humanity, as an array of diverse and morally equivalent groups of peoples and their cultures, was to provide the imagery out from which multiculturalism and identity politics was to develop in the last several decades of the twentieth century. Ironically, advocates of these highly politicized positions have vilified Boas, to the point of even questioning the sincerity of his efforts to counter racism (Visenwaran, 1998; Willis, 1969). 
Boas was not a multiculturalist, nor is it likely that he would have looked favorably on movements of identity politics. As we have seen, he recognized, respected and helped describe many of the mostly small-scale, local cultures with which peoples now identify, but he viewed them as anachronisms, to be documented and then discarded rather than revered. Although he believed that there were things of value in all cultures that might be incorporated into the rational composite of the future, most customs from the past, of his own and other societies, were to him more the "shackles of dogma" (Stocking, 1974, p. 41-42), "the irrational authority of tradition" (Stocking, 1979, p. 96) than something to be accepted uncritically and perpetuated. Boas wished to replace custom with new forms according to which it would be possible to attain the universal rational knowledge that would be the basis for the culture of the future. In his view each of us, as individuals, should be provided the freedom to contribute to and participate in the new way of life being developed. In this sense Boas was an assimilationist and an integrationist. He wanted everyone to participate fully and equally in the new world under construction.

This perspective is the very antithesis of multiculturalism and identity politics. It also strongly opposed the view of American - and world society that followed from the racist, eugenicist and other evolutionary views advocated by his adversaries in his era.

Much of Boas' own research - other than his ethnographic studies focused on testing, with the intent of disproving, the usually unsubstantiated assertions of racist thinkers. Basic to these undertakings was his conviction that human behavior, for the most part, was learned rather than inherent in our biology. This aspect of Boas' program, that was to be a central feature of his anthropological legacy, was made explicit in the work of his students, specifically Margaret Mead.

Mead first met Boas when she was an undergraduate at Barnard College. She pursued graduate studies under his direction at Columbia University because, as she wrote in 1949, he "and Ruth Benedict had presented the tasks of anthropology as more urgent than any other task which lay ready to the choice of a student of human behavior." When she went to $\mathrm{Samoa}^{7}$, in 1924 at the age of 23, she acknowledged her debt to

\footnotetext{
${ }^{7}$ Samoa at the time only recently had become a US possession that had been brought to public attention in the press and in a film by ethnographic filmmaker Robert Flaherty.
}

Horizontes Antropológicos, Porto Alegre, ano 7, n. 16, p. 35-52, dezembro de 2001 
Boas, not only for her training, but also for inspiring and directing her in framing her research problem. The questions she asked were: "Are the disturbances which vex our adolescents due to the nature of adolescence itself or to the civilization? Under different conditions does adolescence present a different picture?" (Mead, 1928) Underlying these questions, and her research, was the much larger issue that was central to the theoretical framework being developed by Boas: To what extent does human behavior derive from biological heritage as against social (cultural) environment?

Coming of Age in Samoa (1928), published shortly after Mead defended her doctoral dissertation, caused a sensation. At one level the book presented a fascinating account of female adolescence in American Samoa; but, at another, it was both a critique of prevailing theories of adolescence advanced by scholars and accepted by professionals and a framework for rethinking the theories and changing practices.

The argument was simple but with devastating implications. Adolescence in the United States, at the time of the study, was believed to be a period of stress and strain. Public opinion was focused on the subject because of the publicity given the activities of some young women during the "roaring twenties." If Mead could show that this was not the case in Samoa, it would prove that the difficulties were not inherent in any inevitable human nature, but were instead the result of the particular forms of child rearing to which American adolescents were exposed. If this were the case, we could change our child rearing practices to mitigate and perhaps even eliminate the difficulties of adolescence, especially as experienced by females.

Several implications of the study for the future of anthropology and its place both in the social sciences and in public thinking and policy formulation must be made explicit. First, what Mead accomplished was to establish in both public understanding and in scientific thought, was that other cultures could be used as a database against which general statements about assumed universal human characteristics and behaviors made exclusively on the basis of observations in the West could be tested. That is, if generalizations made by theoreticians about adolescent girls in the name of science could be shown not to occur in Samoa - or any other culture - this would disprove (falsify) the proposition that it was rooted in our (biological) humanity. Second, if Samoan adolescents behaved 
differently from their North American counterparts it could only be because the behavior (of adolescence) was learned and Samoans had been exposed to different experiences than Americans. If this were so, it followed that adolescent behavior could be changed by modifying the circumstances to which children were exposed.

Here was the truly revolutionary social and political potential of Boas' anthropological paradigm. Human beings were in control of their own behavior. If they did not like something in their culture, they could change it.

The Coming of Age in Samoa, according the Mead, was not written as a "popular" book. It also was not a technical monograph intended for an audience of professional anthropologists or other scholars. Instead, it was a book written in simple and straightforward language "that would be communicative to those who had the most to do with adolescents - teachers, parents and soon-to-be parents," asking them to rethink what they were doing in the light of her report. This idea of transforming behaviors considered to be unwanted or undesirable by modifying other behavior was tremendously empowering. It gave people the ability to transform their lives and their futures.

If Boas, Mead, and an anthropology based the concept of culture as learned behavior that differed from group to group and place to place and was susceptible to being changed were right, people no longer were bound to accept as inevitable social forms received from previous generations. They could change them by changing themselves and what they did. They no longer needed leaders or reformers. They, themselves, could provide the direction.

This was the kind of scientific thinking with which it would be possible to build a more rational, liberal and democratic world. Furthermore, instead of assuming that the traditions of the West, its economic practices, family and kinship patterns, religions and rituals, etc., were the inevitable end point of human evolution and debating who would be permitted to participate in them and to what degree, a new culture could be developed by combining selections from among what was known (and invented) in the West with practices from the range of other cultures being studied. The ethnographic record, as being assembled from the investigations of specific cultures by anthropologists, could be gleaned to find out what in human experience worked and what should be avoided 
(Boas, 1928; Kluckhohn, 1957). If culture was learned rather than innate, and based on one's membership in a group or category, all peoples, no matter their place of birth or upbringing, could participate fully and equally as individuals by learning the new practices. It was never that human behavior could be explained as something determined solely by culture. Rather, before one dare conclude that some specific human activity is universal, based on an untested assumption or studies conducted only in European societies - not to speak of slime molds or laboratory animals as is being done by the present generation of evolutionist scientists - it was necessary to compile data on variations in different cultural settings: only thus could one hope to clarify what was a result of cultural conditioning and what was biology.

America's entry into World War II drastically changed the focus of national concern and with it the framework of political debate. To mobilize for the war effort it was necessary to unify the population that here-to-fore had been kept apart by the separatist ideology that dominated public debate. The integrationist premises of the anthropological science of Boas, Mead and others were more supportive of the need to bring together all members of the national society behind the war effort than its predecessor and alternative. As Karen Brodkin put it in her discussion of the sudden American acceptance of the descendants of European immigrants, "The war against fascism led to a more inclusive version of whiteness." "Instead of dirty and dangerous races that would destroy American democracy, immigrants became ethnic groups whose children had successfully assimilated into the mainstream..." (Brodkin, 1998, p. 36). Under the guidance of this new liberal philosophy that supported the incorporation of its "white" citizens as individuals, America succeeded not only in winning the war, but also in emerging from it as the most powerful nation in the world.

In the post war period the American economy grew rapidly and its society was transformed. With the help of the GI Bill, the sons of once disparaged immigrants went to college and earned degrees that qualified them for jobs in the rapidly growing industries that eventually would become multinational. Aided by FHA and VA mortgages they bought homes in the suburbs where they and their children achieved a degree of assimilation that the earlier political policies based on the separatist philosophy had denied to their parents. 
Programs to rebuild the economies and societies of our allies, and of our European and Japanese adversaries, and beginning a decade later to help develop and "modernize" the new nations emerging from a discredited colonialism, also were guided by the new liberal philosophy that was based on the premise that human behavior and the institutions of society were learned and not rooted in a nature. In the period from the onset of World War II through perhaps the end of the Vietnam War and the height of the Civil Rights movement, a liberal political imagery, based in considerable part on the anthropological view of the world, dominated public thinking in America. It was central in debate and formulation of public policy. Mead became an American icon. Anthropology was accepted as one of the basic social sciences and programs and departments proliferated as part of the rapid growth of universities. The growing number of professional anthropologists, assuming the battle over racism and social acceptance of all citizens had been won, turned their attention away from public debates and social policy issues and devoted their efforts to elaborating the scholarly and academic aspects of the disciplinary agenda.

As the twenty-first century opens, this view of the world many anthropologists came to take for granted is being challenged, within the academy by proponents in fields with names such as sociobiology, evolutionary psychology and molecular biology, and, perhaps more importantly, in civic discourse. Those advocating these new reductionist theories, which are based on the same evolutionary imagery that informed last century's separatist, discriminatory political agendas, point to anthropology as the basis for what people otherwise as diverse in their academic backgrounds and areas of specialization as Edward O. Wilson (1999, p. 200-201) and Steven Pinker (1994, p. 404-412) call the "Standard Social Science Model". They erroneously claim that anthropology attributes the full explanation for all human behavior to learning, culture, or what they oversimplify as environment ${ }^{8}$.

The authors of the many books and papers advocating the new evolutionary reductionisms are neither racists nor eugenicists, but their as

\footnotetext{
${ }^{8}$ These scholars do not use the word culture, nor do they acknowledge and make reference to the database of cross-cultural materials collected by anthropologists that would falsify many of their claims. In fact, they appear to be referring more to the behaviorism of B. F. Skinner and his followers in psychology than to the thinking and research results of anthropology.
}

Horizontes Antropológicos, Porto Alegre, ano 7, n. 16, p. 35-52, dezembro de 2001 
yet unsubstantiated claims that human behavior is to be explained exclusively by means of our genes ${ }^{9}$, support conservative views of social reality that rationalize the status quo (with all of its institutionalized racism and other discriminatory practices) and promote it as inevitable. If our genes alone account for our behavior, it follows that there is nothing much we can do about it other than to acknowledge the social consequences of the world in which we find ourselves and then learn to live with it ${ }^{10}$.

Nelkin and Lindee (1995, p. 100) summarize the implications of the new reductionism for civic discourse and social policy making in words that echo the Calvinist idea of for-ordination. They write:

The appropriation of DNA - the good or bad gene - to explain individual differences recasts common beliefs about the importance of heredity in powerful scientific terms. Science becomes a way to empower prevailing beliefs, justifying existing social categories and expectations as based on natural forces. The great, the famous, the rich and successful, are what they are because of their genes. So too, the deviant and the dysfunctional are genetically fated. Opportunity is less important than predisposition. Some are destined for success, others for problems or, at least, a lesser fate.

If our genes do determine our fate, why should society's resources be expended to educate new immigrants and other minorities doomed to failure? If "criminal" behavior is programmed in their genes, why make the effort to rehabilitate young, black, male offenders? Or, for that matter, why even think about public policy as a means to improve the human condition?

There is much more involved in the nature/nurture debate than an abstract theoretical disagreement among dispassionate scientists. Each side of what continues to be framed in terms of an uncompromising opposition - in

\footnotetext{
9 This position has been followed by most molecular biologists, evolutionary psychologists and sociobiologists since Francis Crick's (1957) first formulated the "dogma" of DNA $\longrightarrow$ RNA $\longrightarrow$ protein, attributing ontological priority exclusively to the genes.

${ }^{10}$ A startling example of this was the recent review in the Sunday New York Times Book Review Section of Mean Genes by Burnham and Phelan, a book in which the authors, according to the reviewer, after accepting the argument for the power of genes to explain human behavior, offer "practical steps for better living" [a self help book to deal with the inevitable consequences of genetic determinism]. Although the book was dismissed intellectually, the fact that the editors of the Times chose to review it demonstrates the influence this line of thinking has in popular literary circles.
} 
spite of repeated denials on both sides - leads logically to significantly different views of the social order. Since neither side is able at present to muster a sufficient combination of theory and data to convince the other, the debate will continue well into the future. In the meantime, I suggest that we consider the public policy implications of both positions, which brings me back to the criticism that Franz Boas' anthropology was more of a social and political agenda than a science. I have argued that in some respects it was; that Boas' anthropology was formulated as the science to counter the prevailing one that, among other things, justified social exclusion, discrimination and prejudice. Today's neoevolutionary, reductionist theories, whether their proponents intend it or not, once more provide "scientific" support for conservative, separatist and often discriminatory social policies.

The more relevant debate is to be found in the realm of politics. In the absence of conclusive proof, why should concerned citizens opt for a position that implies that their social world is the product of forces over which they have no control? Why should they accept that the institutions, rules and practices to be found in the West are inevitable? Would it not be wiser for them to choose the position that leads to the belief that they are the masters of their own destinies? Perhaps it is time for those who believe, as did Boas, Mead and several generations of anthropologists, that human beings are able to invent and implement cultural forms other than those presently found in the West, to raise their voices once more in public debates on social issues where the contest over the discourse that is to inform public policy is being waged.

Although anthropological thinking, its research activities and methodological approaches, have been criticized, both appropriately and not, and have changed in the past half-century, it is now time to reaffirm in public the basic view of the world the discipline continues to teach: that human beings are not simply the products of their genes - mean, selfish or other. With respect to their social, political, economic and other behaviors, they are able to invent and implement practices different from those that dominate our present Euro-American world. It is time for anthropologists to revive their concern with social policy and make it once again central. The result can be, in the spirit of what Carroll said in the epigraph to this paper - and Boas and Mead believed - that the future will be different because we did what was necessary to make the present different. 


\section{References}

BOAS, Franz. Anthropology and modern life. New York: W. W. Norton \& Company, Inc., 1928.

BRODKIN, Karen. How Jews became white folks and what that says about race in America. New Brunswick: Rutgers University Press, 1998.

CARROLL, James. Constantine's sword, the Church and the Jews: a history. Boston: Houghton Mifflin Co., 2001.

COLE, Douglas. The value of a person lies in his "Herzensbildung"; Franz Boas' Baffin island letter-diary, 1883-1884. In: STOCKING Jr., George W. (Ed). Observers observed: essays on ethnographic fieldwork. Madison, Wiscosin: University of Wisconsin Press, 1983.

FREEMAN, Derek. Margaret Mead and Samoa: the making and unmaking of an anthropological myth. Cambridge: Harvard University Press, 1983.

GROCE, Nora Ellen; MARKS, Jonathan. The great apes project and disability rights: ominous undercurrents of eugenics in action. American Anthropologist, 102, p. 818822, 2000.

HARRIS, Marvin. The rise of anthropological theory: a history of theories of culture. New York: Thomas Y. Crowell, 1968.

KUHN, Thomas S. The structure of scientific revolutions. Chicago: University of Chicago Press, 1970.

LEWIS, Herbert S. The passion of Franz Boas. American Anthropologist. In press. MacDONALD, Kevin. The culture of critique: an evolutionary analysis of Jewish involvement in twentieth-century intellectual and political movements. Westport: Praeger, 1998.

MEAD, Margaret. Coming of age in Samoa. New York: William Morrow \& Company, 1928.

NELKIN, Dorothy; LINDEE, M. Susan. The DNA mystique: the gene as cultural icon. New York: W. H. Freeman and Company, 1995.

NISBET, Robert A. Social change and history. London: Oxford University Press, 1969.

PINKER, Steven. The language instinct: how the mind creates language. New York: Harper Collins Publishers, 1994.

STOCKING Jr., George W. Race, culture, and evolution: essays in the history of Anthropology. New York: The Free Press, 1968. 
STOCKING Jr., George W. The shaping of American Anthropology, 1883-1911: a Franz Boas reader. New York: Basic Books, 1974.

Anthropology as "Kulturkampf”: science and politics in the Visweswaran, Kamala "Race and the culture of anthropology". American Anthropologist, 100, p. 70-83, 1998.

WILLIS Jr., William S. Skeletons in the anthropological closet. In: HYMES, Dell (Ed.). Reinventing Anthropology. New York: Random House, 1969. p. 121-152.

WILSON, Edward O. Consilience: the unity of knowledge. New York: Vintage Books, 1999. 